\title{
MELIHAT GEJALA SOSIAL YANG ADA DI MASYARAKAT
}

\author{
Nama : RAFID NAUFAL RAIFTISSIA \\ Email: rafidnaufal26.rn@gmail.com \\ No BP: 2010003600319 \\ Kelas : $1 \mathrm{H8}$ \\ Prodi : Ilmu Hukum \\ Perguruan Tinggi : UNIVERSITAS EKASAKTI
}

\section{A. PENDAHULUAN}

Merebaknya virus Corona atau Covid 19 di beberapa Negara, menimbulkan dampak yang cukup signifikan dan menyebabkan adanya beberapa gejala sosial. Hal tersebut terlihat pada terpuruknya ekonomi, sehingga berimbas kepada banyaknya perusahaan yang tidak dapat bertahan. Akibatnya, terjadi banyaknya Pemutusan Hubungan Kerja (PHK), sehingga menambah jumlah pengangguran dan mendorong masyarakat berada di garis kemiskinan.

Gejala sosial adalah suatu fenomena yang ditandai dengan timbulnya permasalahan sosial yang mempengaruhi dan dipengaruhi oleh tingkah laku setiap individu di dalam lingkungan kehidupannya. Dengan kata lain, setiap gejala ini menjadi dampak sekaligus penyebab dari gejala sosial lainnya.

Gejala sosial adalah hal-hal yang menyebabkan terjadinya masalah sosial. Gejala sosial seringkali disamakan dengan masalah sosial, penting untuk dimengerti bahwa hal ini tidak tepat. Namun, kedua konsep memang saling berkaitan erat. Untuk memudahkan kita dalam membedakan gejala sosial dengan masalah sosial, berikut adalah sebuah contoh yang dapat gunakan untuk memahami masing-masing konsep. Ketimpangan ekonomi merupakan sebuah gejala sosial, gejala sosial tersebut mengakibatkan terjadinya sebuah masalah sosial, yaitu kriminalitas yang dilakukan oleh masyarakat miskin. Istilah "gejala" pada konsep ini berasal dari pendekatan positivisme, yaitu cabang ilmu sosial yang diturunkan dari tradisi ilmu alam. 
Gejala-gejala sosial di dalam masyarakat yang tidak dikehendaki dan diinginkan oleh masyarakat dapat disebut masalah sosial. Hal ini merupakan gejala yang abnormal atau gejalagejala yang patologis. Masalah-masalah sosial begitu mengganggu dan menghantui kehidupan manusia dalam kebudayaan dan peradabannya karena dapat dipastikan hal tersebut dapat menjauhkan manusia dari kesejatraannya

Kehidupan masyarakat sejatinya selalu mengalami perubahan seiring berkembangnya zaman. Dalam proses perubahan tersebut, terkadang muncul kondisi yang tidak diharapkan atau tidak seharusnya terjadi.

Adanya gejala sosial di dalam masyarakat ini memberikan beragam dampak terhadap manusia. Secara umum, ini memiliki dampak baik positif maupun negatif bagi kehidupan bermasyarakat. Dampak positif bisa berupa modernisasi dan gotong royong, sedangkan dampak negatif bisa berupa perang, kejahatan, pengangguran, kemiskinan, korupsi dan kenakalan remaja.

Pada dasarnya semua manusia menginginkan kehidupan yang baik, yaitu terpenuhinya kebutuhan hidup, baik kebutuhan jasmani, kebutuhan rohani, maupun kebutuhan sosial. Manusia berpacu untuk dapat memenuhi berbagai kebutuhan hidupnya demi mempertahankan kehidupan diri sendiri, maupun keluarganya.

Berdasarkan uraian di atas, penulis tertarik untuk membuat makalah dengan judul "Melihat Gejala Sosial Yang Ada Di Masyarakat". 


\section{B. PEMBAHASAN}

Gejala sosial adalah peristiwa-peristiwa yang terjadi di antara dan oleh manusia, baik secara individu maupun kelompok. Kegiatan masyarakat melahirkan gejala sosial.

Gejala sosial dapat terjadi di mana saja, baik di perkotaan maupun pedesaan. Namun, di wilayah perkotaan, profesi lebih beragam daripada pedesaan. Masyarakat di perkotaan pun cenderung heterogen, berbeda dengan di pedesaan yang lebih homogen. Selain itu statifikasi dan diferensiasi sosial di pedesaan lebih sederhana daripada perkotaan.

Gejala-gejala sosial yang ada di masyarakat dapat diartikan sebagai sebuah fenomena sosial. Munculnya fenomena sosial dimasyarakat berawal dari adanya perubahan sosial. Perubahan sosial itu tidak dapat kkita hindari, namun kita masih dapat mengantisipasinya. Perubahan sosial adda yang bersifat positif dan negatif, sehingga kita harus hati-hati dalam menghadapi perubahan yang terjadi. Fenomena sosial yang ada dalam kehidupan sehari-hari dapat dapat menimbulkan masalah sosial. Adapun beberapa contoh fenomena sosial seperti munculnya kesenjangan sosial, demam musik luar (boyband/girlband), pencemaran lingkungan, dan lain sebagainya. Gejala sosial juga diartikan sebagai suatu pristiwa yang sering terjadi pada lapisan masyarakat, baik masyarakat tradisional maupun masyarakat modern.

Macam-macam gejala sosial antara lain:

1. Gejala sosial religious, misalnya perayaan panen padi

2. Gejala sosial ekonomi, misalnya gejala menurunnya pertumbuhan ekonomi dan meningkatkan pengangguran

3. Gejala sosial politik, misalnya terjadinya praktik politik uang untuk memenangkan pemilu

4. Gejala sosial hukum, misalnya ketidakdisiplin pengendara sepeda motor di jalan raya 


\section{Contoh Gejala Sosial}

Contoh Gejala sosial antara lain kemiskinan, kejahatan, perang, kewirausahaan, dan persamaan gender. Setiap gejala sosial menjadi dampak sekaligus penyebab dari gejala sosial yang lain. Misalnya keyakinan agama memengaruhi praktik ekonomi. Sedangkan kepentingan ekonomi menentukan teori politik.

Gejala sosial yang ada didalam masyarakat berawal dari adanya perubahan sosial. Setiap masyarakat pasti mengalami perubahan di lingkungannya. Perubahan sosial merupakan segala perubahan yang ada pada lembaga-lembaga kemasyarakat dan dipengaruhi sistem sosial, nilai, sikap, serta pola prilaku di antara kelompok-kelompok dalam masyarakat.

Perubahan sosial dalam masyarakat dapat berdampak positif maupun negatif. Bagi masyarakat yang tidak dapat menerima perubahan sosial maka akan terjadi masalah sosial. Adapun contoh gejala sosial yang ada pada masyarakat.

1. Kemiskinan Dalam sosiologi, kemiskinan merupakan suatu gejala sosial yang sering kita jumpai dalam kehidupan sehari-hari. Gejala sosial ini terjadi diberbagai negara di dunia termasuk Indonesia. Kemiskinan dapat dibedakan menjadi 2 yaitu:

a. Kemiskinan absolut, yaitu seseorang atau sekelompok orang tidak dapat memenuhi kebutuhan minimum hidupnya.

b. Kemiskinan relatif, yaitu seseorang atau sekelompok orang dapat memenuhi kebutuhan minimum hidupnya, namun dirinya masih merasa miskin bila dibandingakan dengan orang lain atau kelompok lain.

Kemiskinan dapat dikarenakan tidak mampunya seseorang dalam memenuhi kebutuhankebutuhan primer. Namun dalam sosiologi, salah satu faktor penyebab munculnya maslah tersebut karena lembaga kemasyarakatan tidak berfungsi dengan baik, yaitu 
lembagakemasyarakatan dibidang ekonomi. Permasalahan tersebut dapat menyebar kebidang lainnya, seperti pendidikan, sosial, dsb.

2. Masalah remaja

Masa remaja adalah masa pencarian jati diri sehingga banyak remaja yang meniru tingkah laku orang lain. Tindakan remaja bila tidak terkontrol dapat menjadi suatu masalah sosial yang dapat merugikan diri sendiri dan orang lain. Masalah remaja ini ditandai oleh adanya keinginan untuk melawan ataupun sikap apatis. Pada masa ini seharusnya mereka mengenal nilai dan norma-norma yang berlaku dimasyarakat. Dengan mempelajari norma di masyarakat, diharapkan mereka dapat berprilaku dan tidak melakukan perbuatan yang menyimpang. Prilaku menyimpang yang dilakukan oleh remaja dapat beragam, sebagai contoh membolos, mencontek, pelanggaran lalu lintas dan lain sebagainya.

3. Masalah kependudukan

Indonesia adalah negara dengan tingkat kepadatan penduduk yang padat. Penduduk merupakan sumber penting bagi pembangunan. Hal ini dikarenakan penduduk menjadi subjek dan obyek pembangunan. Dengan adanya pembangunan dapat meningkatkan kesejahteraan penduduk disuatu negara. kesejahteraan penduduk juga mengalami gangguan yang dipengaruhi oleh perubahan demografis yang sering sekali tidak dirasakan. Masalah kependudukan dapat berupa kepadatan penduduk, pemerataan penduduk yang tidak rata, ledakan penduduk dsb. Masalah-masalah diatas perlu adanya penanggulangan, karena dapat mempengaruhi tingkat kesejahteraan penduduk. Adapun beberapa cara untuk mengatasi permasalahan tersebut diantanya:

a. Melalui program keluarga berencana $(\mathrm{KB})$

b. Transimigrasi,dan 
c. Mengatur pertumbuhan jumlah penduduk

\section{Faktor Penyebab Gejala Sosial}

1. Faktor Kultural merupakan nilai-nilai yang tumbuh dan berkembang di lingkungan masyarakat/komunitas. Ada beberapa contoh gejala sosial berdasarkan factor kultural, antara lain kemiskinan, kerja bakti, perilaku menyimpang, dsb.

2. Faktor Struktural merupakan suatu keadaan yang mempengaruhi struktur, struktur yang dimaksud adalah sesuatu yang disusun oleh pola tertentu. Faktor struktural dapat dilihat dari pola-pola hubungan antar individu dan kelompok yang terjalin dilingkungan masyarakat. Contoh gejala sosial yang dipengaruhi oleh faktor struktural seperti penyuluhan sosial, interaksi dengan orang lain dsb.

\section{Gejala Sosial Akibat Pengaruh Perubahan Sosial}

Perubahan sosial adalah perubahan yang terjadi dalam masyarakat, berkaitan dengan perilaku.

Perubahan yang dialami masyarakat dipicu:

a. Globalisasi

Globalisasi adalah sistem ekonomi dan budaya global menyebabkan manusia di seluruh dunia menjadi satu kesatuan masyarakat tunggal.

Adanya globalisasi memicu perubahan perilaku ataupun pola pikir.

b. Pola hidup kebarat-baratan (westernisasi)

Westernisasi adalah kecenderungan untuk menjadi sama dengan perilaku masyarakat barat. Westernisasi mengakibatkan lunturnya rasa nasionalisme, menghilangkan jati 
diri bangsa, serta dapat mematikan kreativitas seseorang akibat peniruan budaya barat secara berlebihan.

c. Pola hidup modernisasi

Modernisasi adalah proses pergeseran sikap, karakter, dan perilaku masyarakat dalam menyesuaikan diri dengan perkembangan dunia terkini.

d. Sikap mengutamakan kepentingan dunia (hedonisme)

Orang yang menganut paham hedonisme didominasi oleh perilaku hidup bersenangsenang setiap waktu. Perilaku ini menyebabkan orang yang mengindahkan norma sosial menolak untuk bekerja dan tidak memiliki etos kerja.

e. Sikap hidup boros (konsumerisme)

Konsumerisme adalah kegiatan pembelian barang konsumsi yang berlebihan. Hal itu untuk gaya hidup modern semata.

Terjadinya perubahan sosial-budaya dimasyarakat merupakan salah satu akibat dari gejala sosial. Dampak gejala sosial ada yang bersifat positif dan negatif.

1. Dampak positif

Gejala sosial yang ada di masyarakat harus kita sikapi dengan baik. Bila kita dapat terbuka dan mengimbangi perubahan sosial-budaya yang ada. Maka perubahan tersebut akan berdampak positif dan memberikan kita mamfaat. Hal ini dapat dilihat dengan kemajuan bidang tekhnologi. Dalam bidang tekhnologi kita mengenal tekhnologi komunikasi, seperi telepon, handphone, telegram, email, dsb. Dengan adanya alat komunikasi yang modern, maka, maka kita dapat melakukan interaksi jarak jauh tanpa harus bertemu secara langsung.

2. Dampak negatif 
Seseorang yang tidak dapat menerima perubahan yang terjadi akan mengalami keguncangan culture shock. Ketidak sanggupan seseorang dalam menghadapi gejala sosial akan membawa kearah prilaku menyimpang.

\section{PENUTUP}

Berdasarkan pembahasan yang telah dibuat pada makalah ini, maka dapat disimpulkan bahwa gejala sosial disebabkan oleh:

1. Faktor Kultural merupakan nilai-nilai yang tumbuh dan berkembang di lingkungan masyarakat/komunitas.

2. Faktor Struktural merupakan suatu keadaan yang mempengaruhi struktur, struktur yang dimaksud adalah sesuatu yang disusun oleh pola tertentu.

Pembahasan mengenai gejala sosial yang ada di masyarakat menjadi hal yang sangat penting, karena gejala sosial merupakan suatu fenomena yang ditandai dengan timbulnya permasalahan sosial yang mempengaruhi dan dipengaruhi oleh tingkah laku setiap individu di dalam lingkungan kehidupannya. 


\section{DAFTAR PUSTAKA}

Gokma Toni Parlindungan S, Asas Nebis In Idem Dalam Putusan Hakim Dalam Perkara Poligami Di Pengadilan Negeri Pasaman Sebagai Ceriminan Ius Constitutum, Volume 2, Nomor 1, 2020.

Gokma Toni Parlindungan S, Pengisian Jabatan Perangkat Nagari Pemekaran Di Pasaman Barat Dalam Rangka Pelaksanaan Otonomi Daerah, Ensiklopedia Of Journal, Vol 1 No 2 Edisi 2 Januari 2019,

Harniwati, Peralihan Hak Ulayat Menurut Undang-Undang Nomor 18 Tahun 2004, Volume 1, Nomor 3, 2019.

Jasmir, Pengembalian Status Hukum Tanah Ulayat Atas Hak Guna Usaha, Soumatera Law Review, Volume 1, Nomor 1, 2018.

Jumrawarsi Jumrawarsi, Neviyarni Suhaili, Peran Seorang Guru Dalam Menciptakan Lingkungan Belajar Yang Kondusif, Ensikopedia Education Review, Vol 2, No 3 (2020): Volume 2 No.3 Desember 2020

Mia Siratni, Proses Perkawinan Menurut Hukum Adatdi Kepulauan Mentawai Di Sebelum Dan Sesudah Berlakunya Undang-Undang Nomor 1 Tahun 1974 Tentang Perkawinan, Ensiklopedia Of Journal, Vol 1 No 2 Edisi 2 Januari 2019,

Remincel, Dimensi Hukum Pelanggaran Kecelakaan Lalu Dan Angkutan Jalan Lintas Di Indonesia, Ensiklopedia Social Review, Volume 1, Nomor 2, 2019.

R Amin, B Nurdin, Konflik Perwakafan Tanah Muhammadiyah di Nagari Singkarak Kabupaten Solok Indonesia 2015-2019, Soumatera Law Review, Volume 3, Nomor 1, 2020. 